\title{
DIE BYBELSE BESKOUING VAN DIE MENS AS EENHEID EN DIE BETEKENIS DAARVAN VIR DIE SIELSORG
}

\author{
Deur Ds. J. Steyn*
}

\section{Inleiding}

Sielsorg word aan mense verrig. Vanuit hierdie kensketsing moet nou op twee vrae 'n antwoord gevind word, naamlik : Wat is sielsorg? en wie is die mens aan wie die sielsorg verrig word? Om beide vrae bevredigend te beantwoord sal ' $n$ volledige leer van die sielsorg asook so 'n volledig moontlike bybelse antropologie uitgewerk moet word. So 'n onderneming is vir die Kerk van wesensbelang. Uit die aard van hierdie studie is so 'n opgawe nie moontlik nie. Daarom is velerlei beperking gemaak.

Die Bybelse beskouing van die mens as eenheid kan beskou word as 'n enkele hoofstuk uit baie oor die Bybelse antropologie. En die betekenis van hierdie insig vir die sielsorg maak op sy beurt ook weer 'n enkele hoofstuk in die leer van die sielsorg uit. ${ }^{2}$

Uit die voorafgaande het waarskynlik al geblyk dat hierdie studie gedra word deur die oortuiging dat die Bybelse mensbeeld vir die sielsorg van die Kerk van bepalende belang is. In verband hiermee sê Thurneysen : „Sage mir wie du über den Menschen denkst, und ich will dir sagen was für ein Seelsorger du bist! Alle Verwirrungen in der Seelsorge lassen sich zurückführen auf ein mangelndes oder ein falsches verstehen dessen, was der Mensch ist"' In sy hoofstuk oor die sielsorg skryf Haendler in die paragraaf oor die teologiese grondslae en prinsipes van die sielsorg as eerste sin: „Theologische Grundlage der Seelsorge hinsichtlich ihrer konkreter zuwendung zum Menschen ist die biblische Anthropologie. ${ }^{3}$

\section{Die mens as eenheid}

Wanneer van die mens as eenheid gepraat word, gaan dit in die besander om die gesteldheid van die mens, dit is hoe die

\footnotetext{
- Verhandeling ingedien ter vervulling van 'n deel van die vereistes vir die B.D. graad aan die Universiteit Pretoria, onder leiding van dr. J. I. de Wet, November 1967.

1. Vgl. bv. G. C. v. Niftrik: Zie, de Mens. G. F. Callenbach, Nykerk 1951;

E. Thurnaysen, Die Lehre von der Seelsorge, Zollikon - Zurich 1957 (2).

2. E. Thurneysen, a.w., bl. 56 .

3. O. Haendler, Grundriss der Praktischen Theologie, bl. 317.
} 
mens in werklikheid is. Maar wanneer van die gesteldheid van die menslike syn gepraat word, kan dit nooit heeltemal op sigself beskou word nie. Die hoofstuk oor die gesteldheid van die mens moet in die wyer verband van die Bybelse antropologie gesien word.

Wanneer van die mens gepraat word, moet as eerste en belangrikste gestel word dat hy altyd en oral mens voor God is. Wanneer van hierdie fundamentele gesigspunt afgesien word, kan die wcrklike mens nooit gesien word nie. Die mens staan in ' $n$ bepaalde verhouding tot God. As hiervan afgesien word kan in elk geval nie tot ' $n$ Bybelse beskouing van die mens gekom word nie. „Wie de mens beschouwt afgezien van zijn relatie tot God, houdt zich bezig met een torso af een abstractum."

Die vraag na die gesteldheid van die mens is dus die vraag na die wese van dié mens wat in verhouding tot God staan.

Die sielsorg word beskryf as sorg aan die siel. Om die vraag na die betekenis van "siel" in hierdie verband te beantwoord, gaan Thurneysen uit van die skeppingsberig soos ons dit vind in Gen. 2:7 wat in die vertaling van Luther soos volg lui : „Und Gott der Herr machte den Menschen aus einem Erdenkloss, und er blies ihm ein den lebendigen Adem in seine nase. Und also ward der Mensch eine lebendige Seele." Hieruit konkludeer hy dan dat die mens uit liggaam en siel bestaan cn wel so bestaan dat hy vanuit sy siel dit is wat hy is naamlik die mens. Van hieruit vestig hy dan op vier dinge die aandag, naamlik :

\section{Onderskeidenheid en Eenheid van Liggaam en Siel}

Die onderskeidenheid van liggaam en siel en die geheelheid waarin liggaam en siel op mekaar betrokke is en lê sterk klem op die belangrikheid van die liggaam: "... der Leib ist Wesentbestandteil des Menschen, er ist nichts Nebensächliches, nicht nur ein Anhängsel; eine blosse Behausung oder gar ein Gefängnis in welchem der Mensch seiner Seele nach sich befindet. Seine Humanität hängt also ebensosehr an seinem Leibe wie an seiner Seele..." Deur die inblasing van die Gees of asem (Adem) van God word die mens as eenheid van siel en liggaam mens. Dat die mens in sy geheel deur die inblasing van Gods Gees of Asem bepaal is, maak sy wese as mens uit. Die

4. H. Berkhof, De Mens Onderweg, 's Gravenhage 1965, Vierdie druk, bl. 13.

5. Thurneysen, a.w., bl. 46. 
mens is 'n lewende siel. Wanneer daarom in die sielsorg van die siel van die mens gepraat word, word daarmee eintlik die hele mens, die mens in die eenheid en totaliteit van sy tweeheid van liggaam en siel bedoel. ${ }^{\circ}$

In bostaande is gesê dat die mens uit liggaam en siel bestaan. Dit moet egter nie so opgevat word asof die mens uit twee substansies saamgestel is nie. Dat die mens 'n twee-eenheid van liggaam en siel is, sê nie iets oor die samestelling van die mens nie, maar oor sy wese. ${ }^{7}$

Wanneer gestel word dat die mens in sy tweeheid wesenlik 'n eenheid is, moet teen twee afwykings gewaak word naamlik om die tweeheid in die eenheid of die eenheid in die tweeheid op te los.

As die tweeheid of onderskeidenheid van liggaam en siel verontagsaam word, verval mens maklik in 'n onbybelse monisme. Hierdie monisme kan of na die kant van die liggaam of na die kant van die siel wees. Word die mens net as liggaam gesien dan loop dit uit op 'n materialistiese monisme. Word die mens net as siel gesien, loop dit uit op 'n spiritualistiese monisme.

Die monistiese materialisme ken aan die mens net een substansie toe naamlik sy liggaamlikheid. Volgens hierdie opvatting is dan alleen dit reëel wat liggaamlik, ruimtelik, sinnelik en materieel is. Om hier van 'n aparte siel te praat is „mythologische bevangenheid."s

Die wetenskaplike materialisme het volgens Van Niftrik sy groot mag verkry deur die verbinding met die historiese materialisme van Karl Marx. Die historiese materialisme is wel nie die resultaat van die natuurwetenskaplike materialisme nie, maar dit is 'n grootheid wat die natuurwetenskaplike materialisme gebruik het en waaraan weer die natuurwetenskaplike materialisme sy heerskappy te danke het. ${ }^{9}$

Van Niftrik stel die vraag of die Kerk nie 'n onverskilligheid teenoor die probleem van die materie, van die liggaamlike lewe en dus van die ekonomiese aan die dag gelê het nie. ${ }^{10} \mathrm{Hy}$ konkludeer dan : „De Protestantse theologie heeft het probleem van het lichaam niet willen zien, is al te spiritualistisch geweest,

6. E. Thumeysen, a.w., bl. 46.

7. Vgl. Van Niftrik, Kleine Dogmatiek, 5e druk, Nykerk 1961, bl. 93; H. Berkhof, a.w., bl. 56.

8. G. C. van Niftrik, Zie, de Mens! bl. 328.

9. G. C. van Niftrik, Zie, de Mens!, bl. 330.

10. a.w. bl. 332 . 
heeft het waarheidsgehalte van het materialisme niet willen erkennen ... met het gevolg dat zij in die moderne tyd op een nog veel pijnlijker wijze met dit materialisme van doen kreeg. Hier kan alleen maar baten een nieuwe grondige bezinning op het probleem van des mensen lichamelijkheid ziende op die Mens Jesus, luisterende naar de eschatologische boodschap van de Bijbel." "1

Naas die monistiese materialisme word die monistiese spiritualisme gevind waar die siel as die enigste, „substansie” van die menslike werklikheid gesien word. In teenstelling tot die materialisme word die liggaam hier tot 'n begeleidende verskynsel. ${ }^{12}$ Hierteenoor sal weer opgemerk moet word dat die mens nie alleen liggaam is nie, maar òòk liggaam.

Die monistiese materialisme en spiritualisme is beide te verstaan as 'n reaksie teen die dualisme. Maar hierdie reaksie op sigself is geen waarborg vir die suiwere insig in die menslike natuur nie. ${ }^{13}$

Die dualisme vind ons daar waar die eenheid in die tweeheid opgelos word. Dit is die Griekse visie op die mens, maar wat in die Roomse Kerk en ongelukkig ook in die Protestantse teologie die gangbare is. Volgens hierdie opvatting is liggaam en siel wel aan mekaar verbonde, wesenlik en noodwendig, maar word dit tog opgevat as twee dele van die menslike natuur, waarby elk van beide 'n selfstandige substansie vorm. Die siel is dan die substansie wat geestelik, ruimteloos en onsterflik is, terwyl die liggaam die materiële, ruimtelike en sterflike substansie is. Met so 'n mensbeskouing kom mens dan as vanself tot die opvatting van "die oneindige waarde van die siel" en die anwaarde van die liggaam. Waar die mens so uit twee substansies bestaan wat daarby só verskillend is, kan tog van geen wesenlike eenheid van die mens sprake wees nie, al word dit nog so vurig verdedig. ${ }^{14}$

Naas bostaande dualisme ook die digotomistiese mensbeeld genoem, kom ook die trigotomistiese beeld voor waarvolgens die mens sou bestáán uit liggaam, siel en gees. Prof. G. C. Berkhouwer stel dat die idee van die trigotomie ook nie uit die Christendom opgekom het nie, maar in die Griekse wysbegeerte. Die gedagte vind sy oorsprong in die idee van die bemiddeling,

11. a.w. bl. 333-334.

12. a.w. bl. 334 .

13. Vgl. G. C. Berkouwer: De Mens het Beeld Gods, J. H. Kok, Kampen 1957. bl. 245 .

14. G. C. van Niftrik, Zie, de Mens!, bl. 326-7. 
in 'n skerp teenstelling tussen sienlike en onsienlike dinge. Om die "kloof" wat tussen die twee "wërelde" van die gees (neus) en die liggaam is, te oorbrug, is 'n bemiddelende "siel" ingevoer. wat die band sou moes vorm tussen wat eintlik onverenigbaar is. Dit is dan as die enigste manier beskou waarop nog tot 'n sekere eenheid van die menslike natuur gekom kan word. Berkhouwer kom dan ook tot die slotsom dat die trigotomie sy oorsprong vind in die dualistiese bemiddelingsproblematiek ,waardoor aan de eenheid der menselijke natuur wordt te kort gedaan en een scheppingsmotief wordt ingevoerd met een oorspronkelijk-polaire spanning naamlik tussen geest en stof."15

In die afwysing van die dualisme soos dit gevind word in beide die digotomistiese en trigotomistiese mensbeeld moet egter in gedagte gehou word dat dualisme en dualiteit nie identiek is nie. Met ander woorde wanneer die dualisme afgewys word, beteken dit nie dat ontken word dat daar tog van 'n dualiteit in die menslike natuur gepraat moet word nie. In hierdie verband sê Berkouwer dat van dualisme alleen sprake is wanneer in die dualiteit van innerlike verskeurdheid sprake is, waardeur die eenheid verbreek word. ${ }^{16}$

Wanneer Van Niftrik dan ook van die innerlike struktuur van die menslike kreatuurlikheid praat, wys hy naas die eenheid ook op die differensiasie en ordening van die menslike kreatuurlikheid." ${ }^{1:}$ Hy benadruk dat die mens nie alleen 'n kombinasie van liggaam en siel is nie, maar dat die mens geheel en tegelyk beide siel en liggaam is. $\mathrm{Hy}$ is altyd en in elke verhouding liggaam en siel. Hy vervolg dan ,Enerzijds . . . . . . twee blijven zien: De eenheid van ziel en liggaam betekent niet, dat zij identiek zijn, zodat men ziel en liggaam zou kunnen verwisselen. Anderzyds moeten wij ziel en liggaam steeds samen zien, want de eenheid van ziel en liggaam bestaat niet in een kombinatie van twee elementen, die elk apart beschouwd zouden kumnen worden. Dat is de grote moeilijkheid, die wij niet uit de weg mogen gaan. Er blijven twee momenten, en toch is er eenheid, zodat het ene moment nooit zonder het andere is. Daar komt dan noch een derde moeilijkheid bij, naamlik deze, dat de verhouding tussen ziel en lichaam niet symmetrisch is: De mens is eerst ziel en dan pas lichaam, en niet omgekeerd. Om de concrete werkelijkheid van de mens te zien moeten wij rekenen

15. G. C. Berkouwer, De Mens het Beeld Gods, bl. 228-229.

16. a.w. bl. 232 .

17. G, C. van Niftrik, Zie, de Mens!, bl. 319, 
met de ongelijkheid van hetgeen in de mens verschillend en toch een is. ${ }^{\text {s }}$

Ook op hierdie aspek sal met 'n enkele oorweging volstaan moet word. Wanneer Berkhof na die differensiasie en ordening verwys, sê hy dat ons wel weet dat daar 'n sekere tweeheid is, maar dat ons nêrens die grense en skeidinge kan aanwys nie. Maar daarby is 'n mens digby die Bybelse spraakgebruik wat volgens Berkhof maar een maal die vir ons bekende onderskeiding van siel en "liggaam" die mens in sy totaliteit aandui, die een maal meer vanuit die een gesigshoek en die ander keer weer meer vanuit ' $n$ ander gesigshoek. ${ }^{19}$ Die onderskeidenheid en ordening vat hy dan kortliks só saam: „Er is . . niets te noemen dat uitsluitend tot de ziel of uitsluitend tot het lichaam behoort. Maar er is wel een bepaalde relatie waarin ze tot elkander staan, naamlijk van het leidende tot het geleide, . . . van het regerende element tot het dienende." 20

\section{Geskapenheid van die mens}

Vir die beskouing van die mens as eenheid is ook die tweede saak wat Thurneysen oor die siel van die mens as objek van die sielsorg na vore bring van belang. Die inblasing van die Gees van God waardeur die mens tot 'n lewende siel word of „besiel" word, is 'n handeling van Gód. Die geskapenheid van die mens word dáárdeur uitgedruk dat hy sy lewe as 'n vanGod-verleende lewe leef. Die mens se liggaam is geskape maar ook sy siel. God het Sy asem in die mens geblaas en so het die mens tot 'n lewende siel geword. Dit is 'n besonder sterk argument daarteen om die siel as iets goddeliks of as ' $n$ emanasie van God te beskou. So 'n opvatting word onmoontlik gemaak as bedink word dat „Auch zwischen der Seele und Gott steht der Akt der Schöpfung aus dem sie ihr Leben hat." ${ }^{21}$

In die lig van hierdie insig is ook ,die oneindige waarde van die siel" nie meer te handhaaf nie. Dit is dan ook nie meer moontlik om soos Heering die antwoord op die vraag waarom God die mens soek, te wil beantwoord deur 'n studie van die mens, van sy siel nie. Volgens hom (Heering) kan daardeur duidelik word waarom God juis die méns soek onder al sy skepsels. ${ }^{22}$

18. a.w. bl. 322 .

19. H. Berkhof, De Mens Onderweg, bl. 57.

20. a.w. bl. 57 .

21. Thurneysen, a.w., bl. 47.

22. G. J. Heering, De Menselijke Ziel, 1955, bl. 28 aangehaal by G. C. Berkouwer, De Mens het Beeld Gods, bl. 253. 
Van Niftrik beklemtoon dat die siel nie met die Gees identiek is nie. „Zij dankt haar wezen en existensie aan de Geest”. „,Zij (dit is die siel) is schepsel, gefundeerd door de daad Gods. Wel is de band zier nauw zodat in de Septuaginta ruach G(g)eest wel eens daar psuche, ziel, is vertaald, maar nooit is in de Septuaginta nephesch, ziel door pneuma vertaald. De ziel ist en blijft schepsel: de condescendentie van de Geest heeft geen parallel in een elevatie der ziel." ${ }_{33}$ Die mens is dus geheel en al skepsel dit is vir sy hele lewe na liggaam en siel afhanklik van God.

\section{Die Beeld van God}

Ook in die derde saak wat Thumeysen in verband met die Bybelse antropologie kortliks die aandag op vestig, is dit baie belangrik om die mens as eenheid goed in die oog te hou. $\mathrm{Hy}$ stei dat die mens saam met al die ander kreature wat ook geskape is, in 'n groot lewenssamehang betrokke is en vra dan waarin die mens as geskape wese van al die ander geskapene verskil. Daar moet iets anders wees as net die feit dat die mens deur die ,asem" van God sy lewe het, want dieselfde is ook van die diere waar (vgl. Ps. 104:29-30). Die antwoord op dié vraag vind hy in Gen. $1: 26-27$ : God het die mens na Sy beeld geskape.

Die inhoud van die begrip ,beeld van God" sien hy dan daarin dat God as die Almagtige, persóónlike „Ek is" deur die inblasing van die Gees (of ,asem", „Adem") die mens as 'n „ek is" teenoor Hom laat tree en wel so dat hy God sal verstaan en gehoorsaam. ${ }^{24}$ Die beeld van God bestaan dus daarin dat dia mens in ' $n$ bepaalde verhouding tot God staan. Daar is ' $n$ omgang, 'n verkeer van God en mens, 'n omgang in en deur die Woord van God (En God het gesê: Laat ons ... .) „Durch sein Wort schafft also Gott den menschen Gottes schaffen ist nicht ein mechanisches Machen, ist auch keine Emanation, auch kein blosses Ersinnen und erdenken. Gottes Schaffen ist Sein Sprechen." ${ }^{25}$

God het die mens nie net déur die Woord nie, maar ook vír die Woord geskape. Die mens is geskape as ' $n$,teenoor" 'n antwoordende persoon voor God en vir God. In die geheelheid van sy eksistensie na siel en liggaam moet die mens met God in ontmoeting tree om aan Hom te behoort en Hom te dien soos

23. G. C. van Niftrik, a.w., bl. 322 .

24. E. Thurneysen, a.w., bl. 48-49.

25. Thurneysen, a.w., bl. 50 . 
geen ander skepsel nie..25 „Der ganze Mensch ist Gottesbildlich geschaffen (Von Rad).":

Uit bostaande sal blyk dat elke poging om die imago Dei as iets in die mens te verstaan, afgewys moet word. So 'n poging vind 'n mens in die ook nog steeds wyd verbreide idee selfs onder die lidmate van die Kerk dat die beeld van God uitdrukking is vir iets goddeliks in die mens, dikwels opgevat as die siel. Die begrip beeld van God word substansieel verstaan in plaas van relasioneel. Vanuit die eksegese van Gen. $1: 26-27$ kom Otto Weber tot die gevolgtrekking „dass Imago Dei ganz offenkundig kein Seins - oder Qualitäts-, sondern ein Verhältnisbegriff ist." ${ }^{8}$ Op dié plekke in die skeppingsverhaal waar van die skepping van die mens na die beeld van God gepraat word, is ook af te lei dat dit in sekere onaantasbaarheid van die mens en ook sy heerskappy oor die natuur inhou. ${ }^{29}$ Maar dit maak nie die werklike inhoud van die begrip imago Dei uit nie. „Der Mensch ist das, was er in seiner spezifischen Unantasbarkeit und Herscherstellung ist, kraft eine Beziehung zu Gott, die ihm weder innewohnt noch anhaftet, sondern die ihre Wirklichkeit an dem auftrage erweist, der ihm gegeben wird." 30

Dat die mens na die beeld van God geskape is maak sy wese uit. Hy bestaan, hy ,is" in verhouding tot God en daarom ook in verhouding tot die naaste. Hy ,is" as ,ek" teenoor „U” (God) en "u" (naaste). Die mens is imago Dei insoverre hy in die verhouding tot God staan. Die mens het sy menswees nie in homself nie. $\mathrm{Hy}$ is wat hy is alleen in en deur sy verhouding tot God. ${ }^{31}$ By herhaling word gestel dat dit geld van die mens na siel en liggaam, die hele mens in sy psigosomatiese eenheid. ${ }^{32}$

Daarom is die beslissende vraag vir die mens of hy wel na liggaam en siel onder die genadige aanspraak van God leef of nie. Leef die mens wel onder die aanspraak van God dan het hy in die geheelheid van sy eksistensie na liggaam en siel tot 'n geestelike ,'n pneumatiese mens geword". Leef hy nie daaronder nie dan het hy na liggaam (soma) en siel (psigé) tot die vleeslike (sarkikos) mens geword. ${ }^{33}$

26. a.w., bl. 50 .

27. Aangehaal by A. van Selms, Genesis dl. I, in: Prediking van het Oude Testament, bl. 37.

28. Otto Weber, Grundlagen der Dogmatiek, Bd. I, bl. 618.

29. Gen. 9:5, 6, Gen. 1:26, Ps. 8.

30. O. Weber, a.w., bl. 618. Vgl. ook Th. C. Criezen, Hoofdlijnen der Theologie van het O.T., bl. 447.

31. Sien O. Weber, a.w., bl. 619 .

32. Vgl. A. van Selms, a.w., bl. 36-37.

33. Thurneysen, a.w., bl. 50. 
Omdat die mens 'n persoon is wat God as ,teenoor" vir Homself gestel het, is geen sintese van God en mens moontlik nie. Daar is nic ' $n$ analogia entis van God en mens nie. Tog is daar eenwording van God en mens naamlik in die Mens Jesus. Maar die eenwording is so dat die Seun van God mens word en nie 'n mens die Seun van God nie. Dit is egter nie 'n sintese in die volle sin van die Woord nie, want ook in Jesus Christus is daar 'n grens tussen Skepper en skepsel: God bly God en die mens bly mens (vere Deus, vere homo). Daarom is in Jesus Christus eers werklik die werklike mens te ken, die Mens wat die beeld van God is (Kol. $1: 15$ ) en volkome na siel en liggaam vir God en daarom vir die mens is. ${ }^{34}$

\section{Die Mens as Sondaar}

As vierde en laaste gesigspunt vir die Bybelse antropologie bespreek Thurneysen kortliks die mens as sondaar. Hy betitel self egter nie hierdie paragraaf só nie, maar vat dit saam onder die enkele woord genade. Genade beteken dat die mens voor God staan as sondaar wat vergewing ontvang. Tussen God en die mens staan nie net die akte van die skepping wat God en mens verbind en skei nie, maar ook die donker raaisel van die sonde. Sonde bestaan daarin dat die mens wat daartoe bestem was om God te bely en met Hom om te gaan, sy bestemming nie meer vervul nie. Die mens bestaan nog, maar in die nag van sy sonde, „ein Ich, dem das Du Gottes fremd geworden ist". Hy lewe 'n lewe van die vlees sonder die Gees. Maar genade beteken dat die Woord van God ook en juis tot hierdie mens gerig bly. Die mens bly ook as sondaar 'n van God aangenome mens. Elke woord ook die skeppingswoord van God staan onder die teken van die genadewoord van Christus. God se Woord is van huis uit genadewoord, Sy Gees genade-Gees wat Hom oor die mens ontferm. Die hele handeling van God aan die mens kan saamgevat word in dié daad wat die een en totale daad van God is, naamlik die vergewing van sondes. In die vergewing van sondes deur die genadewoord van God lewe die mens sy lewe as 'n lewe wat na liggaam en siel deur God aangespreek is en vervul so sy bestemming.

Daarom is alle kennis van die mens genade-kennis. Wat ans van die mens weet, weet ons deur Jesus Christus in Wie God se genadewoord aan ons geskied. „Biblisch-theologische Anthro-

34. Thurneysen, a.w., bl. 53. Vgl. Van Niftrik, Zie, de Mens!, bl. 90, bl. 287, Hoofstuk IV, yeral bl. 153 v.y. Sien ook H. Berkhof, De Mens Onderweg, bl. 23. 
pologie ist darum immer und in Ausschliesslichkeit christologische anthropologie.":;

Vanuit hierdie christologiese gesigspunt is dit duidelik dat die mens in sy geheel na liggaam en siel sondaar, maar in Christus ook begenadigde sondaar is. Daarom moet twee opvattinge wat veral wyd verbreid is, afgewys word. Die eerste is dit dat dit by die vergewing van sondes, die verkondiging van die Kerk om die redding van siele (los van die liggaam as selfstandige substansie) gaan. Die ander is dít dat die sonde tot die liggaam beperk is en dat die liggaam daarom deur die siel só onderwerp moet word dat dit as iets vreemds en angewens naas die siel beskou moet word. Volgens hierdie opvatting is dit alleen die liggaam wat aan die sonde blootgestel is, terwyl die siel daarvan gevrywaar is. Emil Brunner stel dat die oorsprong van die sonde eerder in die siel gesoek kan word .... this integration starts from the mind and not from the body. Sin does not issue from the bodily instinct and then enter into the mind and spirit, but it comes from the mind and enters into the bodily instinct." "Only this does not mean that there is a constitutional opposition between mind and body - as though it were of the nature of the mind to disturb the functions of the body - but it means that the mind does not hold fast its God-given destiny, but chooses its own destiny in addition." ${ }^{36}$ Is hierdie beskouing nie ook meer in ooreenstemming met die Bybelse woord dat uit die hart slegte begeertes, moord, egbreek ens. voortkom nie? ${ }^{36}$ -

En is dit nie vanuit ' $n$ visie wat die liggaam as die besonder of alleen-sondige deel of substansie van die mens sien wat dit moontlik word om die erfsonde so materialisties te sien nie? Augustinus het die peccatum originale as concupiscientia, begeerlikheid, gesien en uitsluitlik op die liggaamlike begeerte betrek. Van Niftrik merk tereg op dat so 'n visie die gevolg is van 'n onbybelse, idealistiese antropologie waarby die liggaam as die "laere" gesien word. Van die eenheid van die mens-wees die eenheid van siel en liggaam, het mens dan geen besef nie. Van Niftrik beklemtoon dat die mens as geheel, met sy hele „syn" sondig $^{3-}$ maar daarby is dit ook duidelik dat die vergewing van sondes in en deur Jesus Christus ook vir die hele mens redding beteken. Jesus Christus het immers aan ,liggaam en siel die hele tyd van sy lewe op aarde ... die toorn van God teen die sonde

25. Thurneysen, a.w., bl. 53-33.

36. E. Brunner, Man in Revolt - A Christian Anthropology, vertaling van Olive Wyon, bl. 382-383.

36a. ,Want uit die hart kom daar slegte gedagtes, moord, egbreuk, hoerery, diewery, valse getuienis, lastertaal". (Mattheus 15:19).

37. G. C. van Niftrik, Kleine Dogmatiek, bl. 373-3. 
van die ganse menslike geslag gedra." ${ }_{38}$ Dit het nie net betekenis vir dic siel van die sondige mens nie, maar ook vir sy liggaam. Die gelowige wat die vergewing van sondes bely, bely ook in verband met die ,wederopstanding van die vlees : "... dat ook hierdie selfde vlees van my (liggaam) deur die krag van Christus opgewek ... en aan die heerlike liggaam van Christus gelykvormig sal word." ${ }^{39}$

Met bostaande is probeer om aan die hand van Thurneysen se uiteensetting van die Bybelse antropologie die belangrikste insigte wat vanuit die Skrifgetuienis oor die mens te verkry is, aan te stip. Dit is met 'n bepaalde doel dat uit 'n leuse van verskeie „Bybelse”, ,teologiese” en „christelike” ,antropologieë” juis van Thurneysen se uiteensetting uitgegaan is. Hy bespreek die Bybelse antropologie spesifiek met die oog op die sielsorg, anders gestel: Die belangstelling in die antropologie spruit voort uit die opdrag om aan die mens sielsorg te verrig. Hy wil die mens as objek van die sielsorg vanuit die Skrif verstaan. By hierdie stof wat Thurneysen bied, is gegewens uit die werk van ander teoloë bygewerk om die gegewens van Thurneysen veral onder die gesigspunt van die mens as eenheid te verwerk. Die stof uit ander bronne beteken dus nie noodwendig oral 'n nadere uitleg van wat Thurneysen self sê, sodat hier sprake sou wees van „inlegkunde” nie. Dit moet veeleer beskou word as interpretasie van die Bybelse antropologie veral aan die hand van Thurneysen met inagneming van wat ander outeurs hieroor te sê het en dit alles met die oog op die bepaalde doel van die studie.

Daar is begin by die Bybelse antropologie. Thurneysen self stel dat die uitgangspunt van die Bybelse sielsorg in die Bybelse antropologie geneem moet word. „Nur auf dem Boden wahrer Erkenntnis des menschen ist Seelsorge überhaupt möglich. Das rechte Wissen um den Menschen ist darum notwendiger ausgangspunkt einer rechten Lehre von der Seelsorge. Sie entfaltet sich von ihrem Gegenstand her." „Nicht genug kann man sich darum als Seelsorger vertiefen in das Geheimnis des Menschen. ${ }^{40}$

Die insigte wat uit die Bybelse antropologie verkry is, moet nou op die praktyk van die sielsorg toegepas word. Maar voordat daartoe oorgegaan word, moet in kort aan 'n ander vraag aandag gegee word, naamlik wat is die verhouding van die Bybelse

38. Heidelbergse Kategismus, Sondag XV, Vraag en Antwoord 37.

39, H.K., Sondag 22, Vraag en Antwoord 57.

40. E. Thurneysen, a.w.,, bl. 56 .

41. J. H. van den Berg., Psychologie en Theologische Anthropologie, G. F. Callenbach, Niikerk, de druk, 1963/4, bl. 29. 
mensbeskouing tot die van die psigologie en filosofie. Hierby sal dit alleen maar om 'n pleksbepaling kon gaan.

\section{Bybelse Antropologie, Psigologie en Filosofie}

Verskeie uitsprake oor die mens wat in die hedendaagse psigologie en filosofie gevind word, vertoon 'n merkwaardige ooreenkoms met uitsprake oor die mens wat in die teologie te vind is.

Wat die psigologie betref, vind 'n mens bv. 'n stelling soos : „'s Mensen bestaan is solitair noch wereldloos, doch originair en essensieel met de ander en met de dingen" ${ }_{11}$ Hierdie beklemtoning van die relasionele bepaaldheid van die mens kom ooreen met wat Emil Brunner oor die mens sê : „Der Mensch bekommt sein wirkliches Ich nir von Du her". En Barth stel : „Gott ist das gegenüberstehende $\mathrm{Du}$, ohne das es kein Ich gibt."4?

In 'n bespreking van die eksistensialisme sê Van Niftrik dat dit die Kerk en teologie op 'n nuwe en dringende wyse voor 'n aantal vrae en probleme stel. Hier word net een wat in die verband van die huidige studie van belang is, genoem, naamlik die vraag in hoeverre die christelike mensbeeld in ooreenstemming is met die Bybel. ${ }^{43}$ Die tealogie beweer dat hy alleen by die Woord van God lewe, maar dra in die praktyk 'n hele las van filosofiese oortuiginge (veral van die Aristotelisme en idealisme) met hom saam. Die eksistensialisme wat genoemde sisteme kritiseer en laat wankel, kan ook de teologie help om nou eindelik daarvan af te sien. Dit beteken nie dat die Kerk nou aan die eksistensialisme Kerklike sanksie moet gee nie, (soos vir soveel eeue al die geval met die Aristotelisme en idealisme is nie), maar dat die eksistensialisme die Kerk weer na die ware Bybelse antropologie laat vra."t

Wat nou die verhouding van genoemde wetenskappe tot die Bybelse antropologie betref, die volgende prinsipiële oorweging: Die poimeniek is ' $n$ teologiese wetenskap. Die praxis wat hieruit afgelees word, moet dus noodwendig Bybels-teologies gefundeerd wees. Die sielsorg word bepaal deur sy objek. Om Bybelse sielsorg te kan wees, moet dit werk met die Bybelse mensbeeld. Primêr vir die sielsorg is daarom die Bybelse antro-

42. Aangehaal by J. H. v.d. Berg, a.w., bl. 33.

43. G. C. van Niftrik, De Boodschap van Sartre, G. F. Callenbach, Nijkerk, 2de druk, bl. 140 .

44. G. C. van Niftrik, a.w., bl. 168. 
pologie, want alleen daaruit kan die werklike mens na sy werklike wese geken word. Ware kennis van die mens is genadekennis. Die ware mens kan net uit die geloof in Jesus Christus geken word. ${ }^{45}$

Die psigologie en filosofie, ook die van die moderne tyd, is nie vanuit die geloof in Jesus Christus met die mens besig nie. Daarom kan die werklike mens nie deur dié wetenskappe geken word nie. Mens dink veral aan die eksistensialisme wat as 'n „Thcologie ohne Gott" getipeer is. Die mens wat na sy wese mens vóór God en vír God is, kan nie deur hierdie wetenskap geken word nie. Die Bybelse sielsorg kan daarom nie in een van hierdie wetenskappe sy uitgangspunt neem nie. Ook kan nie een van hierdie wetenskappe op gelyke voet naas die Bybelse antropologie gestel word ten opsigte van hulle betekenis vir die sielsorg nie.

Dit beteken natuurlik nie dat hierdie wetenskappe hulle reg as selfstandige en wettige wetenskappe antsê of dat hul betekenis vir die sielsorg ontken word nie. Ook by hierdie wetenskappe is kennis van die mens. Om hulle kennis van die mens van dié van die teologiese antropologie te onderskei gebruik Barth die begrippe „fenomeen” en „simptoom”. „, . . Jene Wissenschaft meint das Phänomen Mensch, nicht aber den Menschen selbst, den Menschen in Seiner Wirklichkeit." ${ }_{46}$ „Wie de mens op zichzelf beschouwt ziet alleen maar "Phänomene, wij moeten intussen heel deze handelwijze van de abstractie laten varen en beginnen met de mens te zien in zijn verhouding tot God, als we dat doen zullen wij de „Phänomene” niet langer als abstracte verschijnselen zien maar als symptomen, symptomen van de mens zoals hij in relatie tot God bestaat." Wanneer die mens as betrokke op God gesien word, word die fenomene tot simptome, wat as simptome van die werklike mens gewaardeer en in rekening gebring kan word en moet word.4i Samevattend kan dus gesê word dat fenomene van die mens dit is wat van die mens geken kan word sonder kennis van die mens as na sy wese mens voor God. Simptome is dit wat van die mens geken word vanuit 'n kennis van die wese van die mens. Sodra die mens na sy wese vanuit die openbaring van God geken word, kan ook van die fenomene van die mens wat deur onder andere die psigologie en filosofie raakgesien is, as simptome van die

45. Vgl. E. Thurneysen, a.w., bl. 55 .

46. O. Weber, Karl Barths Kirchliche Dogmatiek, 6te Auflage, 1967, S. 105.

47. Mi. P. van Dijk, De mens in het gebeuren van die Godsopenbaring Plaats en betekenis van de mens in de Kirchliche Dogmatik van Karl Barth, J. H. Kok, Kampen, 1963, bl. 174. 
Wanneer bestaande onderskeiding in gedagte gehou word kan die sterk klem wat onder andere Thurneysen en Van Niftrik lê op die nuttigheid en noodsaaklikheid van respektiewelik die psigalogie en filosofie vir die pastor, volledig geld. Eersgenoemde stel in verband met die psigologie: „Das Ansprechen des Menschen im Seelsorgegespräch setzt Menscherkenntniss voraus : Die Seelsorge bedarf darum der Psychologie als einer Hilfswissenschaft die der Erforschung der inneren Natur des menschen dient, und die diese Kenntnis vermitteln kann"'s "... um den Menschen mit dem Vergebungswort anzusprechen, müssen wir über ein moglichst exaktes, methodisches und umfassendes wissen verfügen von seinem seelischen zustand. Ohne ein solches wissen kann unser Reden $\mathrm{zu}$ ihm hin unmöglich zielsicher und heilsam sein."40

T.a.v. die filosofie stel Van Niftrik: „Een theoloog die niet een grote belangstelling heeft voor alles wat er "Philosophisch" wordt gedacht, is niet berekend voor zijn taak. Wil de Kerk de moderne mens, zijn levensbesef en zijn philosophie verstaan, dan zal zij zich met het existensialisme moeten bezighouden. ${ }^{50}$ Hy vra en eis van die Kerk en teologie om bereidwillig na die moderne wysbegeerte en literatuur te luister en waarsku teen 'n ,theologisch ghetto": „In dat ghetto heerst de overmoedige waan, dat de theologie het alleen weet ... en daarom geen andere wetenschap nodig heeft. ${ }^{51}$

By hierdie positiewe waardering kan dit egter nie nagelaat word om by herhaling daarteen te waarsku dat psigologiese en/of filosofiese kennis die kennis van die teologiese antropologie verdring of heeltemal vervang nie. Dit wil voorkom of die gangbare mensbeeld in die teologie van die Kerk maar veral by nie nie-teologies-geskoolde lidmaat van die Kerk nog steeds die Grieksdualistiese is. Dit blyk ook 'n geregverdigde vraag om te vra of in die poimeniek en sielsorg van die Kerk in die huidige tyd nie die gevaar begin dreig dat die psigologie 'n onregmatige plek begin inneem ten koste van die Bybelse antropologie nie.

48. E. Thurneysen, a.w., bl. 174.

49. a.w., bl. 175. 'n Prinsipiële en besonder nuttige studie van verhouding van psigoterapie en sielsorg word gevind by P. J. T. Koekemoer, Terreinverkenning insake die verhouding van Psigoterapie en Sielsorg, in H.T.S., 20ste Jaargang. Afl. 2, Januarie 1965.

50. G. C. van Niftrik, De boodschap van Sartre, bl. 152.

5l. a.w., bl. 153 . 


\section{Die Betekenis van die Bybelse beskouing van die mens as eenheid vir die praktyk van die sielsorg}

\section{Sielsorg is Woordverkondiging}

Sielsorg is Woordverkondiging aan die Enkeling. ${ }^{32}$ Die mens is nie net deur die Woord van God geskape nie, maar ook vir hierdie Woord. Hy is bestem om deur die Woord en in die Woord met God in ontmoeting te tree. Daarom kan die sielsorg in niks anders bestaan as die mededeling van hierdie Woord aan die mens nie. Die sielsorg onderskei hom daarin van die ander gestaltes van die verkondiging (naamlik prediking en kategese) dat dit tot die enkele mens gerig is. Hierdie verkondiging geskied nie in die algemeen nie, maar van persoon tot persooon. Daarom neem dit die gestalte van 'n gesprek aan. Hierdie gesprek onderskei hom daarin van die alledaagse gesprek tussen mense of dié van psigoterapeut en pasiënt dat dit nie net "tweegesprek" is nie maar eintlik 'n „drie-gesprek". Want dit is die gesprek van twee mense in gesprek met God. Hierdie gesprek kom voort uit die Woord van Good en lei na die Woord van God. Dit geld altyd ook al is een van die persone hom nie daarvan bewus of daarvoor bereid nie. Dit is die onontbeerlike voorwaarde van die sielsorggesprek dat dit, „drie-dimensioneel" sal wees: God, mens en medemens. ${ }^{53}$

Die pastor en die lidmaat in hierdie gesprek is beide sondaar voor God, sondaar onder die Woord, die genadewoord van God. $\mathrm{Na}$ sy inhoud is die Woord genadewoord aan sondaars. Daarom gaan dit in die gesprek om die vergewing van sondes deur Jesus Christus. Vergewing van sondes moet hier in sy omvattendste betekenis opgevat word, dit is as samevatting van die hele heil in Jesus Christus. Elke vermindering sal hier 'n verminking van die evangelie beteken, en elke klemverskuiwing 'n verdraaing.

Die vergewing van sonde word verkondig aan die mens as persoon, as eenheid van siel en liggaam. Die woord moet so gebring word dat dit die mens in die totaliteit van sy bestaan as liggaam en siel omvat. „Darin besteht gerade die Macht der vergebung dass der Mensch in ihr nach Leib und Seele für Gott zurückgefordert und unter seine Hand gebracht wird, so wahr auch die Sünde seine ganze Existenz bis in ihre letzten leiblichseelischen Tiefen mit Beschlag belegt hat." ${ }^{54}$ Hierdie terugneem

52. Vgl. E. Thurneysen, a.w., bl. 56-58.

53. Vgl. die reedn genoemde studie van dr. P. J. T. Koekemoer in H.T.S., b1. 76 .

54. E. Thurneysen, a.w., bl. 57. 
van die mens uit die mag van die sonde en dood na die genade van Christus kan saamgevat word in die woord heiliging. Die heiliging beteken dat die mens deur die vergewing van sonde na liggaam en siel vir God opgeëis word. Anders gestel: In die gesprek word aan die mens verkondig dat hy met liggaam en siel, in lewe en in sterwe nie aan homself behoort nie, maar aan sy getroue Saligmaker Jesus Christus wat met Sy bloed vir al sy sondes ten volle betaal het en hom uit alle mag van die duiwel verlos het. (H.K. Sondag I).

\section{Sielsorg aan die Hele Mens}

Vanuit die voorafgaande paragraaf kan nou verder gestel word dat die pastor in die pastorale gesprek praat met ' $n$ mens wat hom elke dag in allerlei konkrete situasies bevind. Die mens met wie hy praat moet ook 'n antwoord vind op die vraag na die sin van die materiële dinge bv. die sin van sy arbeid of die probleem van materiële nood. Oor hierdie en allerlei ander dinge kan en moet ook gepraat word. Dit beteken nie dat die pastor nou in 'n ekonooom of sosiale werker moet verander nie. Ook wanneer met die lidmaat oor bv. sy beroep of materiële nood gepraat word, moet dit so gedoen word dat die lig van die Woord hierop val.s Dit is 'n onontwykbare taak vir die Kerk om die mens ook die Bybelse insig in die proobleem van die stoflike, van die besittings en van armoede by te bring. Wanneer die Woord van God in hierdie dinge suiwer spreek, sal die afgode noodwendig swyg. In die sielsorg moet rekening gehou word met die liggaamlike, die materiële. Wie aan hierdie probleme verbygaan hou hom besig met 'n antropologiese docetisme, waar die liggaamlike as nie-werklike beskou word. Dit is dan ook geen wonder dat die mens wat vanuit so 'n visie aangespreek word, homself in hierdie onwerklike en bowe-al on-Bybelse beeld nie aangespreek weet nie.58 Dit kan alleen vermy word as altyd in gedagte gehou word dat die vergewing van sondes met sy fasette van regverdiging en heiliging, bekering en wedergeboorte sig ook uitstrek oor die liggaam.

In 'n studie ,Die plek van Sielsorg in die christelike Diakonie - Prinsipieel gesien" maak A. J. Zwarts dit anneemlik dat die diakonale sorg naas die prediking, kategese en sielsorg ook 'n gestalte van die verkondiging uitmaak. ${ }^{5 i}$ Die versorging van die mens na die liggaam word immers nie net begeléi deur die Woord (as iets bykomstigs) nie. Dit kom voort uit die Woord en

55. a.w., bl. 117 .

56. Vgl. Helmut Thielicke; Lijden aan de Kerk, Wageningen, s.j., 2de druk, bl. $72-85$. 
lei na die Woord. Dit is nogal 'n vraag of die werk van die diaken altyd so gesien word. Die indruk bestaan tog dat die versorging van die armes en die sorg om die liggaamlike as die sorg om die nie-eintlike deel van die mens beskou word. Is dit nie van hieruit te verklaar dat daar in die praktyk so 'n losse verbinding tussen diakonale sorg en verkondiging bestaan, asof wanneer dit om hierdie diens van die Kerk gaan, die Woord daarby nie van pas is nie? Met die gestadige skeiding tussen verkondiging en diakonale sorg word die moontlikheid al hoe groter dat die werk van die diaken deur ander instansies oorgeneem kan word. Versorging van die armes sonder verkondiging is dieselfde as die sekulêre sosiale opheffing.

Die diakonale sorg sal alleen dan aan sy opdrag voldoen as in die gedagte gehou word dat hy die sorg om die materiële nood van die mens dit altyd gaan om sorg aan die mens wat met sy hele eksistensie bestem is tot ontmoeting met God deur die Woord en in die Woord. Die klem moet baie sterker as wat gewoonlik die geval is op hiérdie sin in die bevestigingsformulier van diakens val : „Daarom is dit goed dat hulle nie alleen met uiterlike gifte nie, maar ook met vertroostinge uit die Woord van God aan die armes en ellendiges hulp bewys."

Die voorafgaande twee oorwegings wil ook gelees word as 'n afwysing van twee afwykings in die sielsorg wat onderskeidelik by die spiritualisme en materialisme tuisgebring kan word. Die spiritualistiese visie is te vind by die piëtistiese sielsorg en die materialistiese visie by die "Social Gospel”.

\section{Piëtistiese Sielsorg}

Die piëtistiese sielsorg wyk dáárin van die Bybelse sielsorg af dat heiliging (verstaan as die daad van die mens) ' $n$ min of meer selfstandige plek inneem naas die regverdiging. Daarby word die stryd tussen die Gees en die vlees of tussen die nuwe en die ou mens herlei tot die stryd binne die mens as 'n stryd tussen siel en liggaam. In plaas daarvan dat hierdie stryd tussen die ou mens (siel én liggaam) en die nuwe mens (siel én liggaam) gesien word as alleen 'n weerspieëling van die stryd op Golgota en by die opstanding, word dit los van Christus gesien. ${ }^{58}$

Die tweespalt wat die sonde in die lewe van die mens bring, word hier nie geheel nie, maar eerder geīntensifeer. Want die tak van die sielsorger is hier om die mens in sy stryd te help

57. H.T.S., 20ste Jaargang, Afl. 2 Januarie 1965.

58. E. Thurneysen, a.w., bl. 64 . 
totdat hy eindelik oorwin het. Kan hierdie sg. oorwinning iets anders wees as die deurvoering van die tweespalt tot 'n eensame selfmoord! Hier is die oproep: Kruisig jou liggaam! in plaas van die verkondiging: Christus het ook vir jou liggaam gesterwe en opgestaan.

In dieselfde lyn as bogenoemde lê onder andere die onBybelse troos wat aan siekes en sterwendes maar ook aan ander lidmate in verband met die dood gegee word. Die sterwe word gesien as die oomblik waarin die liggaam (= die oorsaak en draer van die sonde) afgelê word en die siel (= die sondelose want dié is gered) daarvan bevry word. Wat baat dit om by sulke geleenthede uit die Woord van God te lees as die eksegeet daarby eerder die gees van Plato as die Gees van Christus is? sh $^{\text {sh }}$

Hierdie opvatting raak 'n wyer kring as die sieke en sterwende. Dit raak elke lidmaat. Want die eindverwagting bepaal die teenswoordige lewe van die gelowige. ${ }^{\circ 0}$ Met genoemde eindverwagting word die hele lewe gesien as 'n oefenskool om die alleen-sondige liggaam te kruisig en te dood. Dit is tog iets heel anders as die kruisiging van die ou mens (of natuur) waartoe die doopformulier oproep.

Hierdie vriendskap met die Grieks-dualistiese antropologie bring 'n noodlottige vyandskap met die Bybelse antropologie. Die Bybel ken nie 'n sondige en 'n nie-sondige substansie in die mens nie. Die Bybel ken alleen dié mens wat na liggaam en siel sondig is, maar wat as sondaar ook geheel onder die vergewing van die opstanding van die hele mens staan.

Die vashou aan die Grieks-dualistiese visie op die mens word dikwels verdedig as synde die uitdrukking dáárvan dat die verhouding van die mens tot God as 'n verhouding van verantwoordelikheid blywend is. ${ }^{61}$ Maar deur die invoering van die dualistiese visie word die hoop van die mens verplaas van die lewendmakende Gees van God tot die lewendblywende siel van die mens. Die hoop is nie meer op Christus nie maar op iets in die mens self. Hy kan en moet 'n steunpunt in homself vasgryp. Hierdie is 'n onwerklike steunpunt, want dit is nie die wat die Skrif meld, naamlik die Rots Christus nie.

59. Hierdie teenstelling kom duidelik na vore in die boek van O. Cullman. Onsterfelykheid dor ziel of Wederopstanding der doden? G. C. Callenbach, Nijkerk, Ned. vert. deur I. Herschberg van .,Immortalllité de l'âme ou Resurrection des morts?" sien veral bl. 17-26.

60. Vgl. Emil Brunner, Das Ewige als Zukunft und Gegenwart, SiebensternTaschenbuch (32) Verlag, Munchen - Hamburg, 1955, bl. 100-106.

61. G. C. van Niftrik, Kleine Dogmatiek, bl. 402. 


\section{Sielsorg van die „Social Gospel”}

Die tweede afwyking wat hier uitgewys moet word is die eensydige materialistiese visie op die mens. Dit vind uitdrukking in dié opvatting dat die mens versorg is sodra hy maar kos en klere het en sekere "onvervreembare menseregte" vir hom gewaarborg is. Dit kan in die lig van wat in par. 2 gesê is, nie ontken word dat die mens die stoflike versorging nodig het nie en ook nie dat die Christelike geloof die struktuur van die maatskappy bepaal nie. Maar dit is duidelik dat die materialistiese visie nie die werklike mens op die oog kan hê nie. Wie alleen wil lees: „Bewys weldadigheid aan alle mense” en weier om daarmee saam te lees: „Verkondig die evangelie aan die ganse mensdom" "62 kan sy werk nie meer onder die Kerklike vaandel laat vaar nie.

Hierdie praktyk is blykbaar 'n reaksie op die verontagsaming vaan die liggaamlike, net soos die historiese materialisme se ontstaan 'n reaksie teen die $19 \mathrm{e}$ eeuse spiritualisme is. Die waarheid van die materialisme is dat die mens ook liggaam is. Die waarheid van die spiritualisme is dat die mens ook siel is. Die onwaarheid in beide is die on-Bybelse monisme. Beide het vir die Kerk tot nou toe groot skade berokken, want nie een van die twee sien die mens in sy eksistensiële betrokkenheid op God nie. Daarom spreek nie een van hierdie twee rigtings tot die werklike mens wat in die Woord van God geteken word nie.

Is dit nie vir 'n groot mate deur sy on-Bybelse antropologie dat die Kerk 'n groot getal van die moderne mensdom van hom vervreem het nie? Die mens van vandag voel hom duidelik meer aangespreek deur die eksistensialisme as deur die Griekse dualisme of die idealisme. ${ }^{63}$ Die groot meerderheid van mense voel ook dat hul deur die psigoterapeut beter verstaan word as deur die pastor (dié pastor naamlik wat nog die dualistiese mensbeeld as die een en al aandien. $)^{6 t}$

Slot

Die mens van vandag, ook die gelowige mens in die Kerk, word al meer vervreemd van 'n Kerk waar hy homself nie verstaan ag nie. Dit is 'n dringende vraag aan die Kerk wat hy aan die mens gaan bied. Nóg filosofie nóg psigologie nog enige ander sekulêre wetenskap kan aan die mens 'n laaste en afdoende antwoord gee. Die mens het die sielsorg van die Kerk

62. Vgl. Gal. 6:10. Mk. 16:15.

63. Vgl. G. C. van Niftrik, De Boodschap van Sarte, bl. 11.

64. Vgl. $O$. Haendler, Grundriss der Praktischen Theologie, bl. 313. 
nodig, ook die mens wat hom daarvan nie bewus is of daarvoor nie te vinde is nie. ${ }^{65}$ As die Kerk voortgaan om die dualistiese filosofie die uitgangspunt van sy sielsorg te maak, is hy nie net agter die tyd en by die verkeerde adres nie, maar bowe-al onBybels.

Otto Haendler maak die stelling dat die homiletiek in die Kerk gewoonlik baie prinsipieel is, die kategetiek minder prinsipieel en die poimeniek onprinsipieel.66 Die korreksie in die sielsorg sal dáárby moet begin dat die sielsorg helderheid oor sy objek naamlik die mens moet verkry. Alleen wanneer die sielsorg aan hierdie vereiste voldoen het deur die Bybelse antropologie sy eerste en bepalende woord te laat spreek, mag hy hoop om die mens van ons tyd weer te bereik en te help. Wanneer die sielsorg vanuit die Skrifgetuienis weer die wese van die mens leer ken het, kan die hulp wat die ander wetenskappe kan bied voluit in diens gestel word. So kan gehoop word om die verkondiging van die vergewing van sondes in al sy gestaltes by die werklike mens te bring. Dit is altyd die Gees van God wat oortuig, maar dit hef die opdrag om die getuienis by die werklike mens te bring nie op nie; inteendeel : dit bevestig die opdrag!

65. a.w., bl. 314 .

66. Otto Haendler, Grundriss der Praktischen Theologie, bl. 309. 